\section{Parameters of glycemic control and their relationship with zinc concentrations in blood and with superoxide dismutase enzyme activity in type 2 diabetes patients}

\author{
Parâmetros do controle glicêmico e sua relação \\ com a zincemia e a atividade da enzima superóxido \\ dismutase em pacientes diabéticos tipo 2
}

Vanessa Batista de Sousa Lima', Fabiane de Araújo Sampaio', Daila Leite Chaves Bezerra', José Machado Moita Neto²,

Dilina do Nascimento Marreiro'

\begin{abstract}
Objective: This study assessed the relationship between the parameters of glycemic control, and zinc concentrations in blood and superoxide dismutase enzyme activity in type 2 diabetes patients. Subjects and methods: Seventy-three individuals, aged between 25 and 59 years, were divided into the experimental group (type 2 diabetes patients, $n=36$ ) and control group $(n=37)$. Plasma and erythrocyte zinc concentrations, superoxide dismutase activity, and parameters of glycemic control were analyzed. Results: Mean plasma zinc concentration was $74.1 \pm$ $10.7 \mu \mathrm{g} / \mathrm{dL}$ and $68.8 \pm 9.6 \mu \mathrm{g} / \mathrm{dL}$, erythrocyte zinc concentration was $48.1 \pm 9.5 \mu \mathrm{g} / \mathrm{g} \mathrm{Hb}$ and 41.2 $\pm 8.0 \mu \mathrm{g} / \mathrm{g} \mathrm{Hb}$, and superoxide dismutase activity was $2248.9 \pm 300.0 \mathrm{U} / \mathrm{gHb}$ and $2059.6 \pm 285.4$ $\mathrm{U} / \mathrm{gHb}$, in the experimental group and the control group, respectively $(\mathrm{p}<0.05)$. Conclusion: Type 2 diabetes patients showed a positive response to oxidative stress due to adequate zinc concentration in blood and increased activity of superoxide dismutase, and the enzyme was influenced by serum insulin. Arq Bras Endocrinol Metab. 2011;55(9):701-7
\end{abstract}

Keywords

Diabetes mellitus type 2; zinc; superoxide dismutase; chronic hyperglycemia

\section{RESUMO}

Objetivo: 0 estudo investigou a relação entre parâmetros do controle glicêmico, a zincemia e a atividade da enzima superóxido dismutase em pacientes diabéticos tipo 2. Sujeitos e métodos: Setenta e três indivíduos, de 25 a 59 anos de idade, foram distribuídos em grupo caso (diabéti$\cos$ tipo $2, n=36$ ) e grupo controle $(n=37)$. Foram analisados zinco plasmático e eritrocitário, atividade da enzima superóxido dismutase e parâmetros do controle glicêmico. Resultados: A média de zinco plasmático foi $74,1 \pm 10,7 \mu \mathrm{g} / \mathrm{dL}$ e $68,8 \pm 9,6 \mu \mathrm{g} / \mathrm{dL}$; de zinco eritrocitário foi $48,1 \pm 9,5 \mu \mathrm{g} / \mathrm{gHb}$ e $41.2 \pm 8.0 \mu \mathrm{g} / \mathrm{gHb}$; e da atividade da superóxido dismutase foi $2248,9 \pm 300,0$ $\mathrm{U} / \mathrm{gHb}$ e $2059,6 \pm 285,4 \mathrm{U} / \mathrm{gHb}$ no grupo caso e grupo controle, respectivamente $(\mathrm{p}<0,05)$. Conclusão: Os pacientes diabéticos tipo 2 mostram uma resposta positiva ao estresse oxidativo devido à zincemia adequada e ao aumento da atividade da superóxido dismutase, sendo essa enzima influenciada pela insulina sérica. Arq Bras Endocrinol Metab. 2011;55(9):701-7

Descritores

Diabetes melito tipo 2; zinco; superóxido dismutase; hiperglicemia crônica
${ }^{1}$ Department of Nutrition, Universidade Federal do Piauí (UFPI), Teresina, PI, Brazil ${ }^{2}$ Department of Chemistry, UFPI, Teresina, PI, Brazil

Correspondence to: Dilina do Nascimento Marreiro Rua Hugo Napoleão, 665, ap. 2001 64048-320 - Teresina, PI, Brazil dilina.marreiro@gmail.com

Received on 15/July/2011 Accepted on 4/Nov/2011 


\section{INTRODUCTION}

D

iabetes mellitus is a chronic disease that presents metabolic alterations generally associated with overproduction of reactive oxygen species, which favors damage in the metabolism of lipids, proteins and DNA, as well as cell function disorders, contributing to the onset of long-term diabetic complications (1).

Chronic hyperglycemia in diabetes mellitus has been associated with lipid peroxidation and oxidative lesions in cells, caused by self-oxidation of glucose, elevated flow in the polyol pathway, activation of the protein kinase $\mathrm{C}$, and excessive formation of advanced non-enzymatic glycation end-products. These metabolic disturbances contribute to oxidative stress and compromise the antioxidant defense system in type 2 diabetes patients $(2,3)$.

Lipid peroxidation is involved in the manifestation of complications associated with diabetes mellitus type 2, and is important in the pathogenesis of this disease. Therefore, balancing the antioxidant defense system is important to improve morbidity in these patients (3).

Recently, there has been a growing interest regarding hormonal, nutritional and biochemical disorders found in type 2 diabetes. Studies have shown that the metabolic behavior of zinc, and the activity of antioxidant enzymes appear to be altered in these patients (4). Disturbances in zinc nutritional status are usually associated with a dysfunction in the antioxidant defense system, since this mineral acts as a cofactor of antioxidant enzymes, and contributes to membrane stability $(5,6)$.

The measurement of zinc concentrations in plasma and in erythrocytes, and the activity of the enzyme superoxide dismutase, as well as their relationship with parameters of glycemic control may help to clarify the role of antioxidants in oxidative stress in type 2 diabetes patients.

Therefore, the aim of this study was to evaluate the relationship between the parameters of glycemic control, and zinc nutritional status and the activity of the enzyme superoxide dismutase in type 2 diabetes patients.

\section{SUBJECTS AND METHODS}

This case-control study involved 73 individuals from 25 to 59 years of age, of both genders. Participants of study were divided into two groups: a control group $(n=37$, 27 females and 10 males) and an experimental group (type 2 diabetics, $\mathrm{n}=36,24$ females and 12 males), who randomly sought treatment at an endocrinology practice. In both groups, women were premenopausal.

Type 2 diabetes patients who came to the practice were selected for the study if they met the following criteria: clinical treatment only with oral hypoglycemic agents; absence of complications from diabetes (nephropathy, neuropathy and retinopathy), such as chronic renal insufficiency, cataract and hypertension; absence of any vitamin-mineral supplementation and/ or with other medicines that could interfere with zinc-related nutritional status; and being a nonsmoker. The control group was selected according to the same criteria, and had no family history of diabetes or other chronic diseases. The study was approved by the Ethics Committee of the Institution where it was conducted, and the individuals signed a written informed consent form.

\section{Assessment of nutritional status}

Body mass index (BMI) was calculated using measures of weight in kilograms and height in meters. The classification of nutritional status of participants of the study according to BMI was carried out in line with the criteria of the World Health Organization (WHO) (7).

\section{Evaluation of zinc intake}

Zinc intake was obtained by recording food intake over a 3-day period, and nutritional analysis was made with Nutwin software version 1.5, which uses data from Brazilian Table of Food Composition $(8,9)$. The Estimated Average Requirement (EAR) reference values for zinc were $6.8 \mathrm{mg} /$ day for females, and $9.4 \mathrm{mg}$ /day for males $(10)$.

\section{Collection of biological material and biochemical parameters}

Blood samples $(15 \mathrm{~mL})$ were taken in the morning, from 7:30 to 8:30 am, after fasting for at least 12 hours. Plasma was separated from total blood by centrifugation at $1,831 \mathrm{xg}$ for 15 minutes at $4^{\circ} \mathrm{C}$ (Sorvall ${ }^{\circledR} 4 \mathrm{Kl} 5$ centrifuge). Three aliquots of each plasma sample were diluted at a ratio of $1: 4$ with Milli- ${ }^{\circledR}$ water and directly aspirated into the flame of the atomic absorption spectrophotometer (11). Tryptizol ${ }^{\circledast}$ (Merck) was used as the standard, diluted with Milli- $\mathrm{Q}^{\circledR}$ water and $3 \%$ glycerol at $0.1,0.2,0.3,0.5$, and $1.0 \mu \mathrm{g} / \mathrm{mL}$.

For erythrocyte separation, erythrocyte mass obtained from total blood was washed three times with $5 \mathrm{~mL}$ 
of $0.9 \%$ saline solution, homogenized by inversion, and centrifuged at $2,493 \mathrm{xg}$ for 10 minutes (Sorvall ${ }^{\circledR} 4 \mathrm{Kl} 5$ centrifuge) at $4^{\circ} \mathrm{C}$. After the last centrifugation, saline solution was aspirated, and the erythrocyte mass was carefully extracted using a micropipette, placed in demineralized Eppendorf tubes, and stored at $-20^{\circ} \mathrm{C}$, for zinc and hemoglobin analysis (12). In order to express the results in terms of zinc mass/hemoglobin mass ( $\mu \mathrm{g} / \mathrm{gHb})$, erythrocytes lysed was measured according to the cyanmethaemoglobin method (13).

The analysis of erythrocyte zinc concentration was carried out using atomic absorption spectrophotometry (12). Tryptizol ${ }^{\circledR}$ was used as the reference, diluted at concentrations of $0.1,0.2,0.3,0.5$, and $1.0 \mu \mathrm{g} / \mathrm{mL}$ with Milli- $\mathrm{Q}^{\circledR}$ water. The reference interval for plasma and erythrocyte zinc concentration is $70-110 \mu \mathrm{g} / \mathrm{dL}$ and $40-44 \mu \mathrm{g} / \mathrm{gHb}$, respectively $(14,15)$.

The activity of superoxide dismutase in erythrocytes (Ransod Kit; Randox Laboratories Ltd., Crumlin, Antrin, UK) was determined, in triplicate, using the in vitro method in a Lyasis biochemical analyzer, according to methodology recommended by the manufacturer. The reference interval for superoxide dismutase is 1,102-1,601 U/gHb, according to the Ransod/Randox Kit.

\section{Assessment of glycemic control and lipid profile}

Blood samples $(10 \mathrm{~mL})$ were collected after fasting for at least 12 hours. Analyses of plasma glucose and glycated hemoglobin were performed according to the enzymatic and colorimetric method, and the ion exchange chromatography method, respectively, using Labtest ${ }^{\circledR}$ reagent kits. In the assessment of glycemic control of the experimental group, values of plasma glucose $>130$ $\mathrm{mg} / \mathrm{dL}$ and of glycated hemoglobin $>7 \%$ indicate poor glycemic control, according to the American Diabetes Association (16). Serum insulin concentration was analyzed using the chemiluminescence method. Insulin resistance was assessed using the HOMA-IR index (Homeostasis Model Assessment Insulin Resistance), according to the formula: serum insulin $(\mu \mathrm{U} / \mathrm{mL}) \mathrm{x}$ plasma glucose (mmol/L)/22.5 (17).

Serum concentrations of triglycerides, total cholesterol, HDL-cholesterol, LDL-cholesterol and of VLDL-cholesterol were analyzed according to the enzymatic method. The reference interval for these variables was the one determined by the Brazilian Society of Cardiology (18).

\section{Statistical analysis}

Data were processed and analyzed using the SPSS software for Windows, version 9.0. Student's $t$ test was used to determine whether there were differences on the main variables between the two groups. Pearson's correlation was applied to find out the correlation between parameters of glycemic control, and erythrocyte zinc concentration and activity of superoxide dismutase. Significance was established at $\mathrm{p}<0.05$ a priori for all statistical tests.

\section{RESULTS}

The mean age of the type 2 diabetes patients and control group was $46.0 \pm 7.4$ years and $37.2 \pm 8.6$ years, respectively $(\mathrm{p}<0.05)$. The mean values of body mass index of the experimental group was $27.9 \pm 4.5 \mathrm{~kg} / \mathrm{m}^{2}$, and the control group was $23.8 \pm 2.6 \mathrm{~kg} / \mathrm{m}^{2}(\mathrm{p}<0.05)$. Table 1 shows the results of parameters of glycemic control and lipid profile of the type 2 diabetes patients and control group. Plasma glucose, glycated hemoglobin, HOMA-IR, triglycerides, and total cholesterol were significantly higher in type 2 diabetics $(\mathrm{p}<0.05)$. In diabetic patients, the disease had been diagnosed, in average, $4.0 \pm 2.4$ years before. Mean zinc intake in the experimental group was $16.9 \pm 7.3 \mathrm{mg} /$ day and 10.9 $\pm 3.5 \mathrm{mg} /$ day for males and females, respectively, and the control group was $14.9 \pm 6.5 \mathrm{mg} /$ day and $10.5 \pm$ $3.4 \mathrm{mg} /$ day $(\mathrm{p}>0.05)$. Mean plasma and erythrocyte zinc concentration, and superoxide dismutase enzyme of type 2 diabetes patients and control group are shown in table 2 .

Table 1. Parameters of glycemic control and of lipid profile. Values are presented as means and standard deviation

\begin{tabular}{lcc}
\hline Parameters & $\begin{array}{c}\text { Type 2 diabetic } \\
\text { Mean } \pm \text { SD }\end{array}$ & $\begin{array}{c}\text { Control } \\
\text { Mean } \pm \text { SD }\end{array}$ \\
\hline Plasma glucose $(\mathrm{mg} / \mathrm{dL})$ & $184.5 \pm 71.7^{\star}$ & $82.2 \pm 11.7^{\star}$ \\
Glycated hemoglobin $(\%)$ & $9.3 \pm 3.6^{*}$ & $4.5 \pm 0.4^{\star}$ \\
Serum Insulin $(\mu \mathrm{U} / \mathrm{mL})$ & $18.9 \pm 7.7$ & $19.3 \pm 6.6$ \\
HOMA- IR & $8.7 \pm 4.9^{\star}$ & $3.8 \pm 1.2^{*}$ \\
Triglycerides $(\mathrm{mg} / \mathrm{dL})$ & $189.3 \pm 92.9^{*}$ & $92.6 \pm 21.5^{\star}$ \\
Total cholesterol $(\mathrm{mg} / \mathrm{dL})$ & $202.4 \pm 47.9^{*}$ & $175.3 \pm 22.9^{*}$ \\
HDL-cholesterol $(\mathrm{mg} / \mathrm{dL})$ & $40.7 \pm 9.2$ & $44.1 \pm 7.1$ \\
LDL-cholesterol $(\mathrm{mg} / \mathrm{dL})$ & $123.8 \pm 45.1$ & $112.7 \pm 18.2$ \\
VLDL-cholesterol $(\mathrm{mg} / \mathrm{dL})$ & $37.9 \pm 18.6^{*}$ & $18.5 \pm 4.3^{*}$ \\
\hline
\end{tabular}

HOMA-IR: Homeostasis Model Assessment. * Results are significantly different between type 2 diabetes patients and the control group, student's t test $(p<0.05)$. 
Table 2. Plasma and erythrocyte zinc concentration, and antioxidant activity of superoxide dismutase. Values are presented as means and standard deviation

\begin{tabular}{lcc}
\hline \multicolumn{1}{c}{ Parameters } & $\begin{array}{c}\text { Type 2 diabetes } \\
\text { patients } \\
\text { Mean } \pm \text { SD }\end{array}$ & $\begin{array}{c}\text { Control } \\
\text { Mean } \pm \text { SD }\end{array}$ \\
\hline Plasma Zinc $(\mu \mathrm{g} / \mathrm{dL})$ & $74.1 \pm 10.7^{\star}$ & $68.8 \pm 9.6^{\star}$ \\
Erythrocyte Zinc $(\mu \mathrm{g} / \mathrm{gHb})$ & $48.1 \pm 9.5^{\star}$ & $41.2 \pm 8.0^{\star}$ \\
SOD $(\mathrm{U} / \mathrm{gHb})$ & $2248.9 \pm 300.0^{*}$ & $2059.6 \pm 285.4^{\star}$ \\
\hline
\end{tabular}

SOD: superoxide dismutase. * Results are significantly different between type 2 diabetes patients and the control group, student's t test $(p<0.05)$

Results of the simple correlation analysis carried out to investigate the influence of the parameters of glycemic control on erythrocyte zinc concentration and on the superoxide dismutase activity are shown in table 3 . A positive correlation was found between serum insulin and the activity of the enzyme in type 2 diabetes patients $(\mathrm{r}=0.41, \mathrm{p}<0.05)$.

Table 3. Correlation analysis results for activity superoxide dismutase enzyme and erythrocyte zinc in type 2 diabetic patients

\begin{tabular}{lcccccc}
\hline \multirow{2}{*}{ Parameters } & \multicolumn{2}{c}{ Erythrocyte SOD } & & \multicolumn{2}{c}{ Erythrocyte $\mathbf{Z n}$} \\
\cline { 2 - 3 } \cline { 6 - 7 } & $\mathbf{r}$ & $\mathbf{p}$ & & $\mathbf{r}$ & $\mathbf{p}$ \\
\hline Glucose $(\mathrm{mg} / \mathrm{dL})$ & 0.02 & 0.90 & & 0.23 & 0.18 \\
Insulin $(\mu \mathrm{U} / \mathrm{mL})$ & 0.41 & $0.01^{*}$ & & -0.27 & 0.11 \\
Glycated hemoglobin $(\%)$ & 0.16 & 0.43 & & 0.15 & 0.45 \\
HOMA-IR & 0.22 & 0.22 & & -0.00 & 0.99 \\
\hline
\end{tabular}

HOMA-IR: Homeostasis Model Assessment; SOD: superoxide dismutase; Zn: zinc. * Result is statistically significant $(\mathrm{p}<0.05)$.

\section{DISCUSSION}

In this study, body mass index was significantly higher in type 2 diabetes patients than in the control group, results similar to those by Stefanović and cols. (19) and Rysz and cols. (20). In type 2 diabetes patients, the increase in body mass index and waist circumference contributes to the impairment in glucose tolerance and insulin resistance, and usually is associated with higher concentrations of total cholesterol and triglycerides, and lower concentrations of HDL-cholesterol $(16,21)$. However, the analysis of waist circumference was not carried out, which is a limitation of this study.

Mean plasma zinc concentration of the type 2 diabetes patients was significantly greater when compared with the control group. The concentration of zinc in plasma seems to be dependent on the time of diagnosis, is elevated at the beginning of the manifestation of the disease, and reduced in later periods because of the loss of this mineral in urine caused by chronic complications such nephropathy, which may occur between 5 and 10 years after the onset of the disease $(22,23)$. Thus, it is important to highlight that the average time of diagnosis of the type 2 diabetes was only 4 years.

On the other hand, the results of some studies have shown reduced concentration of zinc in plasma in type 2 diabetic patients $(24,25)$. The results of research that used plasma as a tool to assess zinc nutritional status in diabetic patients have been contradictory. However, it is worth mentioning that plasma is a labile marker because it is kept under constant homeostatic control, and may be influenced by oxidative stress, infection, catabolism and diet $(26,27)$.

Reduced zinc concentrations in plasma in type 2 diabetes patients suggest an elevated loss of this mineral in urine, resulting from hyperglycemia and polyuria, which is not compensated by increased intestinal absorption, and reduction in intestinal excretion of this trace element $(25,28)$. However, the excretion of zinc in urine was not determined, which also is a limitation of this study.

Zinc concentration in erythrocytes showed a statistically significant difference between groups, and was higher in type 2 diabetes patients. These data are consistent with those reported by Batista and cols. (29) and Bravo and cols. (4). In metabolic disorders such as diabetes, erythrocyte zinc concentration may better clarify data on metabolic status (oxidative stress and insulin resistance) of these patients than plasma zinc concentration. The fact that zinc is a mineral that participates in various enzymatic processes in the metabolism, both at molecular and cellular level, its concentration in erythrocytes is more adequate than in plasma to assess nutritional status (30).

Zinc intake of type 2 diabetes patients was higher than recommended for this mineral. However, this does not seems to be the determining factor for the metabolic imbalance of zinc in these patients, because aspects related to the physiopathology of the disease, such as chronic hyperglycemia and poor glycemic control, favor changes in the compartmentalization of the mineral in tissues and body fluids. Some research shows that type 2 diabetes patients with adequate zinc intake present hyperzincuria and elevated concentrations of zinc in erythrocytes, according to data from Marreiro and cols. (31) and Batista and cols. (29), respectively.

Literature reports some factors that possibly contribute to the elevated concentration of zinc in 
erythrocytes in diabetic patients, as demonstrated in this study. According to Cimbaljevic and cols. (6), oxidative damage induced by diabetes seems to be more prominent in the erythrocytes when compared with other tissues, promoting the increase in concentration of antioxidants in these cells, which may explain the erythrocyte zinc concentration found in this study.

Another factor that seems to favor increased concentration of zinc in erythrocytes is related to the role of metallothionein as a regulator of the homeostasis of this mineral. Four subtypes of metallothionein (MT) have already been identified. MT-I and MT-II are expressed in most cells, including erythrocytes. Research carried out in cell culture has shown that oxidative stress in diabetes favors the release of zinc from this metalloprotein, which is then transferred to other proteins and stimulate the increase in the intracellular concentration of this mineral, where it participates in the antioxidant defense system $(32,33)$.

The activity of superoxide dismutase in erythrocytes of type 2 diabetes patients with poor glycemic control was greater than that of the control group, as shown in the study of Likidlilid and cols. (34). For these authors, at the onset of diabetes, there seems to be an increase in the activity of superoxide dismutase to neutralize the excess of superoxide anions produced by the mitochondria, due to high concentration of circulating glucose, which prevents oxidative damage to tissues.

Research conducted in diabetic animals and humans revealed that, as a protection against oxidative stress, many cells stimulate the production of antioxidant enzymes, which appears to be due to the need of these enzymes in specific tissues. The overproduction of reactive oxygen species is common in compartments with high energy demand such as skeletal muscle, liver and erythrocytes. The activity of superoxide dismutase appears to be the first antioxidant defense to be stimulated in response to adaptation to oxidative stress, and is high due to its greater demand in these tissues, a fact that could explain the results for this enzyme in this study. However, the increase in the activity of this antioxidant enzyme is not sufficient to compensate for the excessive production of reactive oxygen species in these patients $(35,36)$.

Chronic hyperglycemia in type 2 diabetic patients is a contributing factor to the self-oxidation of glucose and increased rate of cell respiration, which favors the increase in the synthesis of superoxide anions and intracellular concentration of nitric oxide. Thus, to prevent the formation of peroxynitrite anion, there is a compensatory increase in the activity of superoxide dismutase. Therefore, these metabolic alterations, characteristic of diabetes, may have promoted the increased activity of this enzyme observed in this study (37).

The results of lipid profile analysis showed high concentrations of total cholesterol and triglycerides in type 2 diabetes patients when compared with the control group. In diabetic patients with poor glycemic control, elevated concentration of total cholesterol and triglycerides favors the overproduction of lipoperoxides (markers of lipid peroxidation) due of oxidative stress. This mechanism may promote a higher activity of superoxide dismutase, indicating a compensatory response to oxidative stress, which would probably explain the values for the activity of this enzyme found in this study $(21,38)$.

On the other hand, some studies have shown a reduction in the activity of superoxide dismutase in patients with type 2 diabetes $(1,20)$. According to Michiels and cols. (39), in type 2 diabetes patients, the self-oxidation of glucose caused by high concentration of circulating glucose produces an increase in the formation of hydrogen peroxides, which inhibit the enzyme.

Another factor that may contribute to decreased activity of superoxide dismutase is the non-enzymatic glycation of protein sites of superoxide dismutase caused by chronic exposure to hyperglycemia, which inactivates this enzyme and, thus, promotes the accumulation of superoxide anions and products derived from oxidation of superoxide dismutase, which are elevated in the erythrocytes of diabetic patients (40).

An important aspect to be considered is related to the results of the analysis of the relationship between parameters of glycemic control and superoxide dismutase activity. There was a significant positive correlation between serum insulin and superoxide dismutase activity in type 2 diabetes patients $(\mathrm{r}=0.41, \mathrm{p}<0.05)$. These data may be explained by the fact that the increase in serum concentrations of insulin appears to promote a greater demand for superoxide dismutase activity (41).

According to Wittmann and Nagy (42), the high production of superoxide anions can reduce the effect of nitric oxide in the insulin signaling system and, therefore, appears to promote the manifestation of insulin resistance in diabetic patients. The study of Pavlovic and cols. (43) also investigated the effect of insulin on the activity of superoxide dismutase. For these authors, the increased secretion and sensitivity to insulin prevent 
non-enzymatic glycation of superoxide dismutase and promotes the increase in the activity of this enzyme, which contributes to the neutralization of superoxide anions, thus minimizing the effects of resistance to insulin produced by oxidative stress.

In conclusion, this study showed that, as the nutritional status of zinc in type 2 diabetes patients was adequate, there was positive response to oxidative stress due to increased activity of superoxide dismutase, and this enzyme was influenced by serum insulin. Further studies that investigate the relationship between anthropometric parameters (waist circumference) and oxidative stress markers, and evaluates the urinary excretion of zinc in patients with type 2 diabetes may help to clarify aspects related to the involvement of antioxidants in oxidative stress in these patients and, thus, contribute to the development of strategies for the prevention and treatment of disorders associated with diabetes.

Disclosure: no potential conflict of interest relevant to this article was reported.

\section{REFERENCES}

1. Ramakrishna V, Jailkhani R. Oxidative stress in non-insulin-dependent diabetes mellitus (NIDDM) patients. Acta Diabetol. 2008;45(1):41-6.

2. Mlinar B, Marc J, Janez A, Pfeifer M. Molecular mechanisms of insulin resistence and associated diseases. Clin Chim Acta. 2007;375(1-2):20-35.

3. Pan HZ, Zhang L, Guo MY, Sui H, Li H, Wu WH, et al. The oxidative stress status in diabetes mellitus and diabetic nephropathy. Acta Diabetol. 2010;47(suppl 1):71S-6S.

4. Bravo A, Araújo S, Vargas ME, Mesa J, Souki A, Bermúdez V, et al. Actividad de la enzima antioxidante superóxido dismutasa y niveles de cobre y zinc em pacientes com diabetes mellitus tipo Arch Venezolanos de FarmacolTerap. 2007;26(1):1-7.

5. Agte VV, Nagmote RV, Tarwadi KV. Comparative in vitro uptake of zinc by erythrocytes of normal vs Type 2 diabetic individuals and the associated factors. Diabetes Nutr Metab. 2004;17(8):343-9.

6. Cimbaljevic B, Vasilijevic A, Cimbaljevic S, Buzadzic B, Korac A, Petrovic V, et al. Interrelationship of antioxidantive status, lipid peroxidation, and lipid profile in insulin-dependent and non-insulin-dependent diabetic patients. Can J Physiol Pharmacol. 2007;85(10):997-1003.

7. World Health Organization (WHO). Obesity: preventing and managing the global epidemic. Technical Report Series 2000, n. 894.

8. Anção MS, Cuppari L, Draibe AS, Sigulem D. Programa de apoio à nutrição Nutwin: versão 1.5. Departamento de Informática em Saúde SPDM 2002; Unifesp/EPM1 CD-ROM.

9. Tabela Brasileira de Composição de Alimentos/NEPA-Unicamp. NEPA-Unicamp, Campinas, São Paulo; 2006, p. 113.

10. Institute of Medicine/Food and Nutritional Board Dietary reference intakes for vitamin $\mathrm{A}$, vitamin $\mathrm{K}$, arsenic, boron, chromium, cooper, iodine, iron, manganese, molybdenun, nickel, silicon, vanadium, and zinc. National Academy, Washington, DC; 2001, p. 650.

11. Rodriguez MP, Nazarino A, Demczylo V, Cid A. A simpler method for the determination of zinc human plasma levels by flame atomic absorption spectrophometry. At Spectrosc. 1989;10:68-70.
12. Whitehouse RC, Prasad AS, Rabbani PI, Cossack ZT. Zinc in plasma, neutrophils, lymphocytes, and erythrocytes as determined by flameless atomic absorption spectrophotometry. Clin Chem. $1982 ; 28(3): 475-80$.

13. Van Assendelft, OW. The measurement of hemoglobin. In: Izak G, Lewis SM (eds.). Modern concepts in hematology. NewYork: Academic Press, 1972. p. 14-25.

14. Gibson RS. Assessment of chromium, copper and zinc status. In: Gibson RS (ed.). Principles of Nutritional Assessment. New York: Oxford University Press, 2005. p. 711-30.

15. Guthierie HA, Picciano MF. Micronutrient minerals. In: Guthierie HA (ed.). Human nutrition. New York: Mosby, 1994. p. 351-7.

16. American Diabetes Association/ADA. Standards of medical care in diabetes. Diabetes Care. 2010;33(suppl 1):11S-61S.

17. Matthews DR, Hosker JP, Rudenski AS, Naylor BA, Treacher DF, Turner RC. Homeostasis model assessment: insulin resistance and beta-cell function from fasting plasma glucose and insulin concentrations in man. Diabetologia. 1985;28(7):412-9.

18. Sociedade Brasileira de Cardiologia. IV Diretriz Brasileira sobre Dislipidemias e Prevenção da Aterosclerose. Arq Bras Cardiol. 2007;88(suppl 1):2S-19S.

19. Stefanović A, Kotur-Stevuljević J, Spasić S, Vekić J, Zeljković A, Spasojević-Kalimanovska V, et al. HDL-2 particles are associated with hyperglycaemia, lower PON1 activity and oxidative stress in type 2 diabetes mellitus patients. Clin Biochem. 2010;43(15):1230-5.

20. Rysz J, Błaszczak R, Banach M, Kedziora-Kornatowska K, Kornatowski T, Tanski W, et al. Evaluation of selected parameters of the antioxidative system in patients with type 2 diabetes in different periods of metabolic compensation. Arch Immunol Ther Exp. 2007;5(5):335-40.

21. Soliman GZ. Blood lipid peroxidation (superoxide dismutase, malondialdehyde, glutathione) levels in Egyptian type 2 diabetic patients. Singapore Med J. 2008;49(2):129-36.

22. Gross LJ, De-Azevedo JM, Silveiro PS, Canani LH, Caramori ML, Zelmanovitz T. Diabetic nephropathy: diagnosis, prevention, and treatment. Diabetes Care. 2005;28(1):164-76.

23. Jansen J, Karges W, Rink L. Zinc and diabetes-clinical links and molecular mechanisms. J Nutr Biochem. 2009;20(1):399-417.

24. Aguilar MV, Saavedra P, Arrieta FJ, Mateos CJ, González MJ, Meseguer I, et al. Plasma mineral content in type-2 diabetic patients and their association with the syndrome metabolic. Ann Nutr Metab. 2007;51(5):402-6.

25. Viktorínová A, Toserová E, Krizko M, Duracková Z. Altered metabolism of copper, zinc, and magnesium is associated with increased levels of glycated hemoglobin in patients with diabetes mellitus. Metabolism. 2009;58(10):1477-82.

26. Hess SY, Peerson JM, King JC, Brown KH. Use of serum zinc concentration as an indicator of population zinc status. Food Nutr Bull. 2007;28(suppl 3):403S-29S.

27. Lowe NM, Fekete $K$, Decsi T. Methods of assessment of zinc status in humans: a systematic review. Am J Clin Nutr. 2009;89(6):2040-51.

28. Marjani A. Plasma lipid peroxidation zinc and erythrocyte $\mathrm{Cu}-\mathrm{Zn}$ superoxide dismutase enzyme activity in patients with type 2 diabetes mellitus in Gorgan City (South East of The Caspian Sea). Internet J Endocrinol. 2005;2(1):1-8.

29. Batista MN, Cuppari L, Pedrosa LFC, Almeida MG, Almeida JB, Medeiros $A C$, et al. Effect on end-stage disease and diabetes on zinc and copper status. BiolTrace Elem Res. 2006;112(1):1-12.

30. Kruse-Jarres JD, Rükgauer M. Trace elements in diabetes mellitus. Peculiarities and clinical validity of determinations in blood cells. JTrace Elem Med Biol. 2000;14(1):21-7.

31. Marreiro DN, Martins MPSC, Sousa SSR, Ibiapina V, Torres S, Pires LV, et al. Urinary excretion of zinc and metabolic control of patients with diabetes Type 2. Biol Trace Elem Res. 2007;120(1-3): 42-50. 
32. Mason AZ, Perico N, Moeller R, Thrippleton K, PotterT, Lloyd D. Metal donation and apo-metalloenzyme activation by stable isotopically labeled metallothionein. Mar Environ Res. 2004;58(2-5):371-5.

33. Li X, Cai L, Feng W. Diabetes and metallothionein. Mini Rev Med Chem. 2007;7(7):761-8.

34. Likidlilid A, Patchanans N, Peerapatdit T, Sriratanasathavorn C. Lipid peroxidation and antioxidant enzyme activities in erythrocytes of type 2 diabetic patients. J Med Assoc Thai. 2010;93(6):682-93.

35. Aydin A, Orhan H, Sayal A, Ozata M, Sahin G, Isimer A. Oxidative stress and nitric oxide related parameters in type II diabetes mellitus: effects of glycemic control. Clin Biochem. 2001;34(1):65-70.

36. Gumieniczek A, Hopkala H, Wojtowicz Z, Nieradko M. Differences in antioxidants status in skeletal muscle tissue in experimental diabetes. Clin Chim Acta. 2001;314(1-2):39-45.

37. Komosinska-Vassev K, Olczyk K, Olczyk P, Winsz-Szczotka K. Effects of metabolic control and vascular complications on indices of oxidative stress in type 2 diabetic patients. Diabetes Res Clin Pract. 2005;68(3):207-16.

38. Mahboob M, Rahman MF, Grover P. Serum lipid peroxidation and antioxidant enzyme levels in male and female diabetic patients. Singapore Med J. 2005;46(7):322-4.
39. Michiels C, Raes M, Toussaint O, Remacle J. Importance of Se-glutathione peroxidase, catalase and $\mathrm{Cu} / \mathrm{Zn}$ SOD for cell survival against oxidative stress. Free Radic Biol Med. 1994;17(3):235-48.

40. Carmeli E, Coleman R, Berner YN. Activities of antioxidant scavenger enzymes (superoxide dismutase and glutathione peroxidase) in erythrocytes in adult women with and without type II diabetes. Experimental Diab Res. 2004;5(2):171-5.

41. Zbronska H, Grzeszczak W, Jendryczko A, Zbronski R, Kuzniewicz R. Activity of superoxide dismutase in erythrocytes and leukocytes and levels of zinc and copper in blood of patients with diabetes. Effect of diabetic treatment on examined parameters. Pol Arch Med Wewn. 1995;94(3):228-34.

42. Wittmann I, Nagy J. Are insulin resistance and atherosclerosis the consequences of oxidative stress? Diabetologia. 1996;39(8):1002-3.

43. Pavlović D, Kocić R, Kocić G, Jevtović T, Radenković S, Mikić, et al. Effect of four-week metformin treatment on plasma and erythrocyte antioxidative defense enzymes in newly diagnosed obese patients with type 2 diabetes. Diabetes Obes Metab. 2000;2(4):251-6. 